\title{
The Role of Geography in Managing Spatial Development Processes: the Case of the Peri-urban Area of Shkodër City, Albania
}

\author{
Dritan Rustja
}

\begin{abstract}
This paper analyzes the spatial transformations that occurred in the peri-urban area of Shkodër city after 1990, particularly the "Rrethinat" commune, which has experienced the most dramatic social, economic and land use transformations in the Shkodra region during this period, along with Shkodër city itself. This is the first study undertaken for this area and it aims to examine the causes, the dynamics and the impact of these transformations on the community and on land use. Using a problem-resolving (applied) approach, the study finds that the most immediate problems that need to be addressed are: the lack of an administrative identity for this area, the high degree of economic, demographic and settlement informality and the lack of an adequate public infrastructure. It concludes by emphasizing the necessity to develop and carry out a general regulatory plan for this territory, as the final solution to all the above-mentioned problems, and as a way to achieve sustainable development.
\end{abstract} city

Key words: spatial development, peri-urban area, socio-economic changes, Shkodër

\section{Uloga geografije u upravljanju procesima prostornog razvoja: primjer periurbanog prostora Skadra}

U članku se analizira prostorna transformacija periurbanog prostora grada Skadra nakon 1990., s posebnim osvrtom na općinu Rrethinat, koja je reprezentativni uzorak dinamičnih socioekonomskih promjena izraženih u načinu iskorištavanja zemljišta u regiji Skadra. Ovo je prva takva studija za to područje u kojoj su istraženi obrasci, dinamika i utjecaji transformacija. Aplikativnim geografskim pristupom identificirani su sljedeći problemi: nepostojanje administrativnog identiteta, visoki stupanj neformalne (sive) ekonomije, dinamični demografski rast, izgradnja neplanskih stambenih naselja i nedovoljna razvijenost osnovne komunalne infrastrukture. Zaključno se naglašava neophodnost izrade i implementacije master-plana za to područje kao najbolje rješenje navedenih problema te kao način ostvarenja održivog razvoja.

Ključne riječi: prostorni razvoj, periurbani prostor, socioekonomske promjene, Skadar (grad) 


\section{INTRODUCTION}

Regional and spatial planning has traditionally been one of the main areas for application of geographical knowledge and skills (Phlipponneau, 2004). Their interaction is so evident that in many European universities Applied Geography is more-or-less synonymous with Regional Planning: both because its content is appropriate and because so many geographic techniques have clear benefits (Gaspar, 2004).

Within regional and spatial planning itself, the processes of urban growth, urban sprawl and land-use conflict on the urban fringe are among the most important and interesting areas where Applied Geography can make its contribution (Clark, 1999).

The urban fringe means those areas just beyond the build-up part of a city; however, still close enough to it to be subject to intense development pressures. It is above all a place of heightened land-use conflict, uncertainty and profit, hence its interest to geographers. Much geographical research on urban fringe areas is focused on whether and how to plan for the transition from rural to urban, and the consequences of trying to plan the process (Clark, 1999).

Urban growth and the informal development that accompanies it is not a novel issue for Europe. The southern and south-eastern part of the region has long experience in dealing with this problem (UN-HABITAT, 2010). In some post-socialist countries, the formation of informal settlements is a phenomenon associated with the wave of urbanization in the 1960s and 1970s, in others, a phenomenon related to the influx of immigrants and refugees in the 1990s (Tsenkova, 2009) - and this is the case of Albania, where:" the last two decades have been the period of the most dramatic spatial transformations ever occurred. The transition into a democratic system was accompanied with new and unknown challenges for the Albanian society: internal demographic migration of huge dimensions, massive abandonment of the mountainous and rural areas, rapid and chaotic urbanization, informality, social conflicts, poverty, opportunities and hope" (World Bank, 2007).

The uncertainty of land tenure and the legal framework vacuum created by the collapse of the communist regime made it easier to claim a lot of vacant land in the immediate periphery of cities (World Bank, 2006). Indeed, in the absence of laws and regulations, the only way to develop land and build houses was to do it informally. More than everywhere else, these rapid transformations were reflected on the urban fringe of the largest cities, especially Tirana - the capital. Similar informal settlements have also sprung up in all major secondary cities such as Durrës, Elbasan, Fier, Vlorë and Shkodër.

\section{STUDY AREA}

Shkodër, the largest northern city of Albania, also suffered considerably in this respect and is the focus of this case-study. We have been concentrated on analyzing the spatial transformations that occurred in its peri-urban area after 1990, which is almost completely part of a formally rural administrative unit, the "Rrethinat" commune (Fig.1a, 1b). As an opened ring, this commune surrounds the largest northern city of Albania, except on the western side, where both of them are confined by Shkodra Lake. It has an area of 54.2 $\mathrm{km}^{2}$ and a population of 24000 inhabitants (Anonymous 1, 2010). The settlements that 
constitute it are: 1. Bardhaj, 2. Bleran, 3. Dobraç, 4. Golem, 5. Guci e Re, 6. Grudë e Re, 7. Hot i Ri, 8. Shtoj i Ri, 9. Shtoj i Vjetër, and, 10. Zues. Physio-geographically speaking, this area is predominantly lowland (the altitude varies between 10-388 m). It has a mild Mediterranean climate; it is rich in water resources and has fertile soils which favour their cultivation (Gruda, 1991; Hoti, 1996).

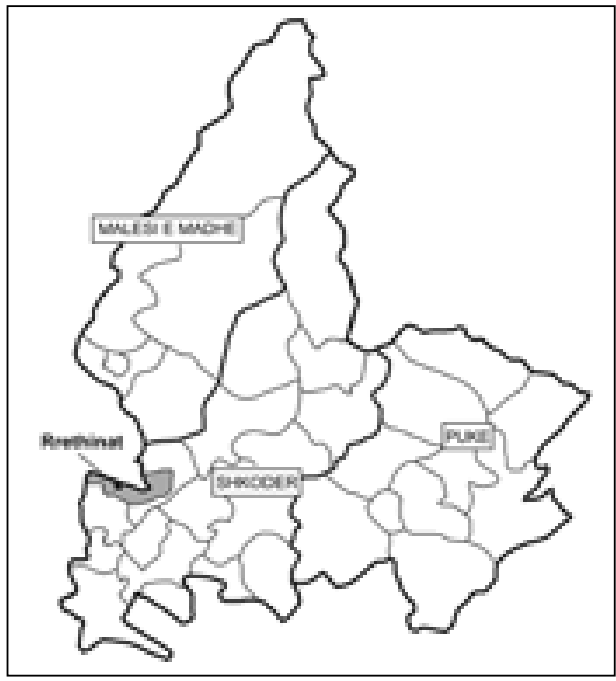

Fig. 1a Location of"Rrethinat" commune on the outskirts of Shkodër city

Sl. 1a. Lokacija općine Rrethinat u predgrađu Skadra

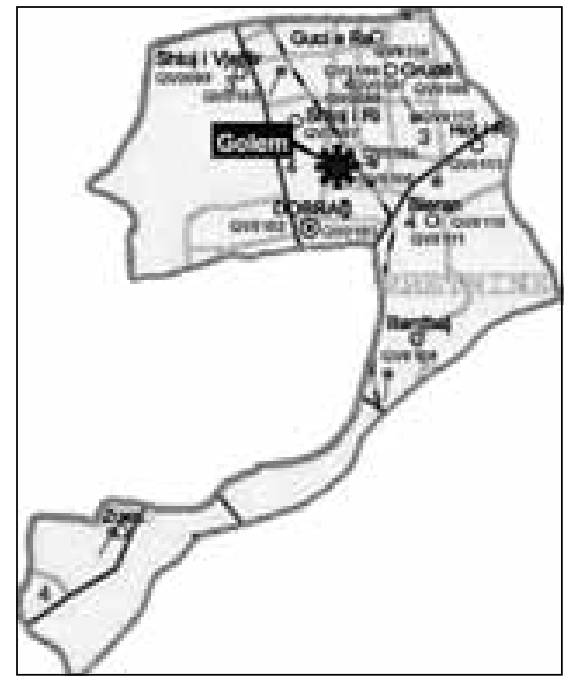

Fig. 1b Map of "Rrethinat" commune on the outskirts of Shkodër city

Sl. 1b. Karta općine Rrethinatu predgrađu Skadra

\section{METHODS AND MATERIALS}

This study is the first one undertaken for this area and has been realized in the framework of applied geographical research. Its methodological approach is based on the protocol of Applied Geography, offered by Pacione - where the procedure can be summarized as: description (problem identification), explanation (problem analysis), evaluation (development of alternative programmes - recommendation), prescription, implementation and monitoring (Pacione, 1999).

In its theoretical framework, the study covers the first three steps of the procedure but, of course, it intends to offer something useful to the policymakers and stakeholders at the local and regional level of governance.

Clark suggests that, when it comes to land-use conflict on the urban fringe, the applied geographer has four possible roles: a) the gatherer of information - to understand what is happening there; b) the interpreter - to provide an explanation of the processes that are unfolding on the fringe; c) the forecaster - how the situation will evolve and how policy should change; d) the advocate - the geographer becomes an advocate for a particular position in which he/she believes (Clark, 1999). While conducting this research, each of these roles has been taken into consideration. 
To provide a description and understanding of the characteristics of the study area in the spatial and temporal context and to analyze the information, use has been made of the secondary data available, which was taken into account and verified using field work and participant observation. Questionnaire surveys, semi-structured and in-depth interviews with key actors and focus groups were also conducted, and the available remotely sensed imagery of the study area was used for this purpose.

\section{Demographic changes}

\section{RESULTS}

During the last two decades, the number of the population in the study area has more than doubled, from 9000 inhabitants as it was in 1992 (when this administrative unit was constituted) to 24000 inhabitants at present (Fig. 2). This increment is mainly a result of the internal demographic migration that placed large numbers of people from the rural and mountainous areas of the Shkodra region in the suburbs of Shkodër city; and much less a result of the natural increase of the local population itself. The motivation behind this demographic migration lies in the hardship of creating and maintaining a living for these people in their remote and unfavourable areas.

Their placement on the outskirts of the Shkodra urban area was stimulated by the chaos that characterized the transition period of Albanian society into a democratic system, and by the uncertainty of land tenure (Alia et al., 2003). Nevertheless, it is very likely that the real population number in this area is much greater than what the official statistics say (some unofficial sources give an estimation of 35000 inhabitants). This is likely to be true because of: a) the high degree of informality which characterizes this commune, b) the large number of self-declarations ${ }^{1}$ made by its inhabitants in the actual process of legalization - 2397 (ALUIZNI, 2009) ${ }^{2}$ and c) by the fact that many incoming families continue to be registered as residents in their original administrative units, even though they actually live in the "Rrethinat" commune - motivated by the fact that financially, their social subsidence is larger there, as it is a mountainous area (Rustja, 2010).

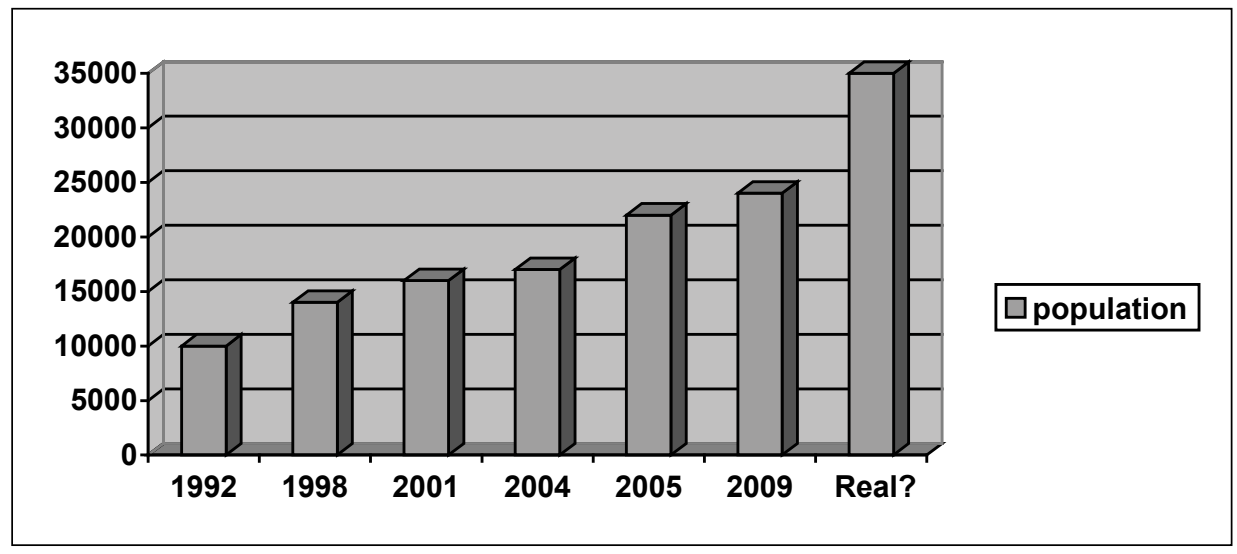

Fig. 2 The growth of population in the "Rrethinat" commune 1992-2009

Sl. 2. Rast stanovništva općine Rrethinat od 1992. do 2009. 
Meanwhile, the density of the population in the study area, again according to the official statistics, is 445 persons per square kilometre, four-fold higher than the average of Albania. These figures show the increased rate of the urbanization process of this commune, particularly of the settlements closer to the urban border, such as Dobraç and Zues, but it is also remarkable in Golem and Shtoj i Ri. On the other hand, as we move away from the city border into the communes' periphery, we notice that the rural patterns become more and more visible. The settlements of Guci e Re, Shtoj i Vjetër and Bardhaj are typical in this respect.

\section{Socio-economic changes}

In spite of the diversity of problems manifested during the transition period, it should be stressed that the quality of life for the people of this area has generally improved, due to a mixture of factors such as: the establishment of a free- market economy and a liberal political system, the distribution of land, private initiative, emigration, the general improvement of living conditions on a national scale, the up-growth of competition and personal ambition, etc. At present, the most tangible social problems evidenced in this commune are: poverty (which affects $20 \%$ of the families) - intertwined with unemployment (Anonymous 1, 2010), and the increased rate of social differentiation, social conflicts and segregation, primarily as a result of the mixture of people with different backgrounds, enhanced by the conflicts on land tenure and prejudgments (Rustja, 2010).

Agriculture continues to be an important economic activity for many people in this "rural" administrative unit, especially for the relevance it has in the percentage of people employed. However, its structure has changed during the transition period, as the importance of some traditional cultures such as grain and maize have been substituted by the widespread cultivation of fodder, vegetables, fruit trees and vineyards. The farming products of this commune have their significance in supplying the needs of the urban population of Shkodër city (Anonymous 2, 2010).

Concerning the other economic sectors, the importance of the agro-industry should be stressed, but especially of the service and construction sectors in this area, which have prospered under the free-market system. The largest number of private businesses is concentrated in the suburban corridor that connects the cities of Shkodër and Koplik, notably in Dobraç and the Shtoj i Ri settlements (ADF, 2006; Anonymous 2, 2010).

\section{Land-use changes}

Referring to the abovementioned changes, it is understandable that the most remarkable transformations that occurred in the peri-urban area of Shkodër city after 1990 are the ones reflected in the use of land, because the high population growth brought rapid and primarily informal development of the construction sector. The incoming population settled mostly on the agricultural land of previously state-owned farms (Instituti i Misrit dhe Perlat Rexhepi), where ownership of the land was unclear after 45 years of communist rule; soon they began to build their houses there. On the other hand, the earlier residents of this area also began to build new houses on their private plots of land, which they acquired 


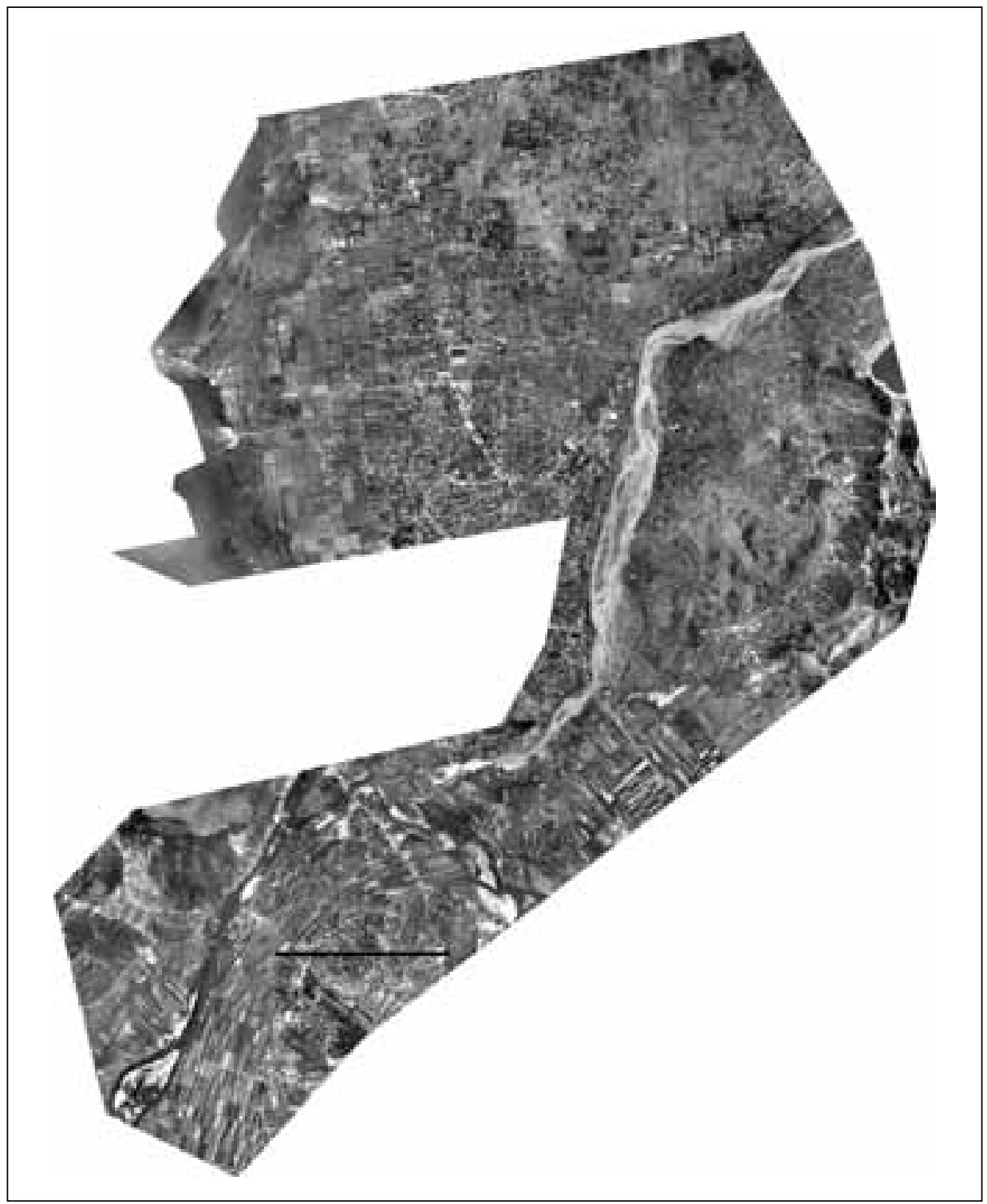

Fig. 3 Orthophoto map of the study area

Sl. 3. Ortofotografska karta promatranog područja

under the new agrarian reform, stimulated in this process by the gradual disintegration of the large family (Laçi, 2005). As a result, 9 informal settlements (zones) with an area of 700 ha that are undergoing the process of legalization (ALUIZNI, 2009) have been created (and are actually defined) on the territory of the "Rrethinat" commune. 
This unprecedented spreading of spontaneous and chaotic settlements in the periphery of Shkodër city has transformed this area into a dynamic place with clear-cut peri-urban patterns (Fig. 3). The few remaining state-owned lands, due to the lack of attention and use, have been converted into informal areas for urban and communal waste. The situation is not very much different regarding the one-time industrial structures and plants, which have badly degraded (Rustja, 2010).

Actually, a relatively large area of the commune's territory is used for urban purposes, serving to supply the necessities of the Shkodra municipality, where its cemetery, agricultural market and water supply plant (which paradoxically provides drinking water for only one of its villages) are worth mentioning, (Tab. 1).

Finally, the cropland still in use is facing the risk of erosion and degradation, stimulated by its fragmentation or abandonment; and the same holds even for the rich ecosystem of Shkodra's lakeshores (Rustja, 2010).

Tab. 1 Actual use of land in the study area

Tab. 1. Način iskorištavanja zemljišta u promatranom području

\begin{tabular}{|c|c|c|}
\hline $\mathbf{N r}$ & Land use & Area (ha) \\
\hline 1 & Agricultural land & 1692 \\
\hline 2 & Informal areas & 700 \\
\hline 3 & Cemetery & 22.5 \\
\hline 4 & Urban land & 500 \\
\hline 5 & Pasture and forest & 102 \\
\hline 6 & Unproductive land & 170 \\
\hline & Total & $\mathbf{3 1 9 6 . 5}$ ha \\
\hline
\end{tabular}

Source: Statistical data from "Rrethinat" commune cadastral office

\section{Problem identification, analyses and evaluation}

By analyzing the abovementioned spatial transformations that have occurred in this area in the last 20 years, it can be found that the most immediate problems needing to be addressed are:

\section{a) The lack of an administrative identity: rural, urban or peri-urban?}

As a result of the dramatic changes that have occurred, the area closer to the "yellow line" (urban border) ${ }^{3}$ demonstrates a mixture of urban and rural patterns, due to the high buildings density, the scant cropland available and its fragmentation, the rapid development of the service sector and the distinct involvement of local people in non-agricultural economic activities; in summary there are few indications of a rural area (Fig. 4 a).

On the other hand, as long as this intensively developed area continues to be classified as agricultural land, it will be very difficult for it to be efficiently managed by the limited capacity building of the local governing authorities (World Bank, 2007). It is evident that in this case there is a need for an administrative reclassification of this territorial unit. 


\section{b) Informality}

As already mentioned, the number of self-declarations of informal buildings to be legalized in the study area is 2397 , ranking it second in the Shkodra region, just behind the municipality of Shkodra (ALUIZNI, 2009). Informal constructions were probably the most practical way to provide shelter for the large incoming population in this area after 1990 but, at the same time, they have resulted in increased social and legal conflicts, particularly

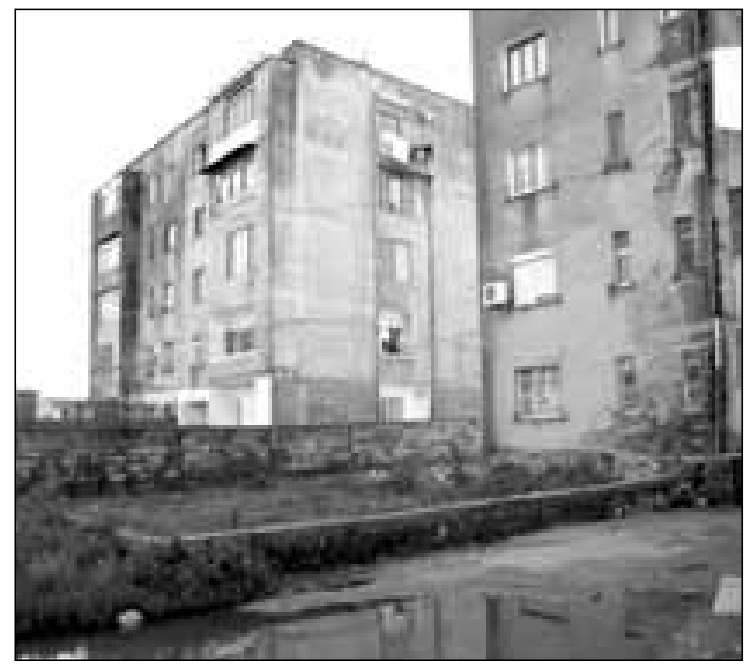

Fig. 4a Evidence of the urban-rural interference Sl. 4a. Primjeri interferencije ruralnih i urbanih elemenata about land tenure and possession, which remains an open question (Fig. 4 b). Informality is an issue even in the demographic context, as no-one at present can give an exact estimation of the population number in this administrative unit. Equally problematic is the economic informality, notably in the service sector, where many businesses along with their employees are not formally licensed and recorded. So, it seems clear that the challenge of regularizing and integrating the informal character of settlements, economy and demography is of a high priority.

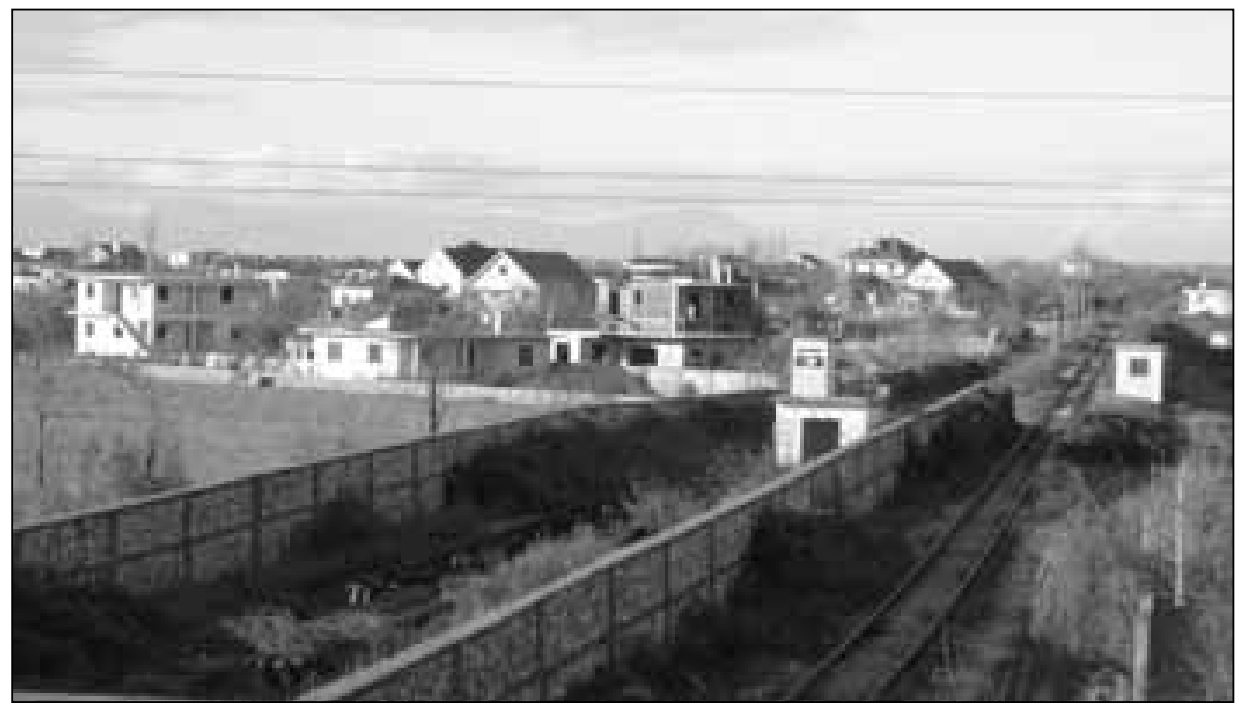

Fig. $4 \mathrm{~b}$ Extention of the informal settlements Sl. 4 b. Širenje neplaniranih naselja 
The Role of Geography in Managing Spatial Development Processes:

the Case of the Peri-urban Area of Shkodër City, Albania

\section{c) Lack of an adequate public infrastructure}

These rapid spatial transformations have not been followed by the necessary investments in public infrastructure. Most of them have been directed towards the improvement of the road network system and, to some extent, education facilities, leaving outside the authorities' attention the sewage and drainage system, the management of urban and communal waste and the adequate supply of the local population with drinking water and electrical power.

So, it is evident that this area necessitates the construction of a new water supply plant, an electric power station, and a landfill adequately to serve the needs of the increased population; the old ones actually in use are outdated and inefficient. The road system also needs to be improved; the construction of Shkodër - Han i Hotit highway is of particular relevance (Rustja, 2010).

\section{RECOMMENDATIONS}

All the afore-mentioned problems could be summarized under one denomination: the necessity to develop and implement a general regulatory plan for this area. This plan should reflect its current and future development trends and should be in cohesion and coordination with the other regional and national regulatory plans, especially with the structural urban plan of Shkodër city.

This regulatory plan has the potential to solve the problems stressed above, as the suburban informal settlements cannot currently be provided with the adequate infrastructure because of their administrative status; being outside "the yellow line" (but highly developed) the informal settlements are still considered as agricultural land.

In this respect, taking into account the existing projects about the administrative re-classification of Albania's territory, there is a need to relax and even extend the urban growth boundary of the Shkodër municipality, which should include the most urbanized areas of the commune such as the Dobraç and Zues settlements. This regulatory plan can be made effective only after the completion of the ongoing process of legalization and the resolution of the opened conflicts over land ownership ${ }^{4}$.

This regulatory land-use plan should include clear definition of subdivision regulations (zoning), which seems to be essential for the urbanization process on the urban fringe. In this context, specific areas of the peri-urban land have the potential to serve as business districts, department stores, university campuses, public parks etc., complementing in this way the needs of the constantly growing urban population of Shkodër city. The same zoning process should clearly define the areas opened for public use - especially for infrastructure purposes - and the spaces that will remain for private use and other purposes. 


\section{DISCUSSION AND CONCLUSIONS}

The way the urban fringe works reflects the wider economy and society of a country (Clark, 1999). In the case of Albania, the dramatic transformations it has experienced since the transition have had very clear spatial dimensions, while the urban development and migration phenomena taking place at the same time have been correcting a spatial structure that evolved under central planning, adjusting to the emerging marketplace. The swell of migration, seemingly chaotic and spontaneous, has reflected Albanians' natural and practical responses to the new geography of opportunity (World Bank, 2007).

It can be argued that the process of urbanization in Albania has gone through three distinct phases since the fall of communism. The first phase was dominated by the informal sector. The second phase saw the consolidation of the informal and the emergence of a formal sector. The third and current phase consists of further establishing the formal sector and regularizing the informal development. Bringing these settlements under legal status and linking them to the urban networks remains one of the key challenges for Albania if it is to modernize and integrate its urban economies (World Bank, 2007).

In the case of Shkodra's peri-urban area, it can be said that the patterns of development have been similar to the ones unfolding on a national scale. After the completion of the actual process of legalization, which was chosen by the government as the most viable solution to formalize and integrate the informal settlements, the next step will be the provision of an adequate infrastructure.

Spatial planning is not provided during the legalization process, since it was considered impractical under current circumstances, because any contemporary development proposal must deal with fragmented land and property units in a mix of complicated and disputed private and public ownership. This is being left to be implemented at a later stage in the future, after the legalization process and the compensation of previous owners.

This study argues and concludes that this stage should not be much delayed; if not, additional transformations that will certainly occur in the future will make comprehensive and spatial planning in these area(s) very difficult, if not impossible, to implement. It also suggests that a low level of planning at present, designating areas for development and ensuring sufficient space for infrastructure and civic amenities, can be applied.

\section{NOTES}

1 Self-declaration - self-declared informal constructions that are undergoing the process of legalization, built after 1990.

2 ALUIZNI (Agency for Legalization, Urbanization and Integration of Informal Zones) is the national agency set up in 2006 to manage the programme of "legalization and urbanization of illegal settlements and buildings" in Albania.

3 The "yellow line" divides the built-up city areas from the rural ones, and usually coincides with the administrative border 
The Role of Geography in Managing Spatial Development Processes:

the Case of the Peri-urban Area of Shkodër City, Albania

4 The main characteristics of the legalization procedure are: a) Legalization: issuing of ownership titles for land and buildings; squatters must pay a fixed price for the land they have occupied. b) Compensation: the money paid by the squatters is collected by the legalization agency and will be used partially for improvements, partially to compensate previous owners. c) Urbanization: infrastructure provision and comprehensive spatial planning to the informal settlements that are legalized will take place after legalization (UN-HABITAT, 2010).

\section{REFERENCES}

Albanian Development Fund (ADF), 2006: Regional Development Strategy of Shkodra and Lezha, Qarku Shkodër, (Shkodra District), Shkodër.

ALUIZNI, (Agency for Legalization, Urbanization and Integration of Informal Zones), 2009: Data from Shkodra's Regional District, Shkodër, Albania

Alia, B., Lulo, K., Myftiu, G., 2003: Tirana: The Challenge of Urban Development, CETIS, Tirana.

Anonymous 1, 2010: Statistical data from "Rrethinat" commune offices, Shkodër, Albania.

Anonymous 2, 2010: Statistical data from the Agriculture and Food Directory, Shkodër, Albania.

Gaspar, J., 2004: Applied geography in Western and Southern Europe, in: Applied geography, a world perspective (eds. Bailly, A., Gibson, L.J.), Kluwer Academic Publishing, Dordrecht, 151-169.

Clark, G., 1999: Land-use conflict at the urban fringe, in Applied Geography; Principles and Practice (ed. Pacione, M.), Routledge, London, 301-309.

Gruda, Gj., 1991: Mbishkodra plain, in Physical Geography of Albania, Volume II, Academy of Sciences of Albania, Tiranë, 454-465

Hoti, M., 1996: Physio-geographic patterns of Mbishkodra plain, Geographical Studies 4, 159-172.

Laçi, S., 2005: Rural Geography, Progress, Tirana.

Pacione, M., 1999: In pursuit of useful knowledge: the principles and practices of applied geography, in: Applied Geography; Principles and Practice, (ed. Pacione, M.), Routledge, London, 1-19.

Phlipponeau, M., 2004: Historical foundations of applied geography, in: Applied geography, a world perspective (eds. Bailly, A., Gibson, L.J.), Kluwer Academic Publishing, Dordrecht, 47-69.

Rustja, D., 2010: Interviews with local leaders, specialists and residents of "Rrethinat" commune, Shkodër, Albania.

Tsenkova, S., 2009: Housing Reforms in Post socialist Europe: Lost in Transition, Springer-Verlag, Heidelberg.

UN-HABITAT, 2010: Informal urban development in Europe: experiences from Albania and Greece, Technical Chamber of Greece, Athens.

World Bank, 2007: Albania Urban Sector Review, World Bank Office, Tirana.

World Bank, 2006: Albania - Status of Land Reform and Real Estate Market, World Bank Office, Tirana.

Received (Primljeno): 2010 - 12 - 29

Accepted (Prihvaćeno): 2011 - 10- 09 
Hrvatski geografski glasnik 73/2 (2011.)

Dritan Rustja

Department of Geography

Faculty of Social Sciences

University "L. Gurakuqi"

Shkodër, Albania

tan_rustja@yahoo.com 